\title{
Decolorization of two azo dyes using marine Lysobactersp. T312D9
}

\author{
Khouloud M. I. Barakat \\ Marine Microbiology Lab., Division of Marine Environment, National Institute of Oceanography \& Fisheries, Alexandria, Egypt. \\ E.mail: kh2m2@yahoo.com
}

Received 26 July 2012; Received in revised form 25 September 2012; Accepted 27 September 2012

\begin{abstract}
Aims: Novel azo dye-degrading bacterium T312D9 strain has been isolated from Abou Quir Gulf, Alexandria, Egypt.

Methodology and Results: The identification of the isolate by 16S rRNA gene sequencing revealed to be Lysobacter sp. This marine ecofriendly isolate was exploited for its ability to degrade two synthetic azo dyes considered as detrimental pollutants from industrial effluents: congo red and methyl red. Using different dye concentrations showed the highest metabolic activity for complete degradation obtained from 100 to $500 \mathrm{mg} / \mathrm{L}$ within $30 \mathrm{~h}$ under static condition, also, sustaining higher dye loading of 1 $\mathrm{g} / \mathrm{L}$ was carried out. The significant induction of enzymes $\mathrm{NADH}$ - 2,6-dichloroindophenol (NADH-DCIP) reductase and tyrosinase indicated their prominent role in dye degradation. The biodegradation of two azo dyes were analyzed by gas chromatographicmass spectrum analysis (GC-MS) and Fourier transform infrared spectroscopy (FTIR) before and after treatment. Toxicity study revealed the much less toxic nature of the metabolites produced after complete decolorization.

Conclusion, significance and impact of study: Lysobacter sp T312D9 represent an inexpensive and promising marine bacteria for removal of both methyl and congo red. High sustainable metabolic activity for biodegradation under static condition. NADHDCIP reductase and tyrosinase were significantly induced during biodegradation of dyes. The obtained metabolites revealed to be less toxic in nature which offers a practical biological treatment.
\end{abstract}

Keywords: Lysobacter sp, decolourization, azo dyes, enzyme activities, GC-MS, FTIR, toxicity

\section{INTRODUCTION}

Synthetic azo dyes have a wide application in the food, pharmaceutical, textile, leather, cosmetics and paper industries (Adedayo et al., 2004). These synthetic dyes are extremely stable under exposure to light and washing and also resistant to aerobic biodegradation. The discharge of these industrial colored effluents results in creating undesirable conditions that are lethal to resident organisms (Khehra et al., 2006). Several methods are used in the treatment of textile effluents to achieve decolourization but they have many disadvantages and limitations (Figueroa et al., 2009).

Biological processes provide alternative technologies that are more cost-effective and environmentally friendly (Asad et al., 2007). Many microorganisms belonging to the different taxonomic groups of bacteria have been reported for their ability to decolorize azo dyes (Telke et al., 2008; Mendes et al., 2011a; Feng et al., 2012). Many marine microbes are capable of degrading azo dyes, including bacteria (Priya et al., 2011), fungi (Saritha et al., 2010), actinomycetes (Mane et al., 2008) and algae (Ergene et al., 2009). In recent years, there has been an increasing interest in bacteria that have potentiality to degrade or mineralize several azo dyes without shaking condition (Kumar et al., 2006; Kalyani et al., 2009; Mansour et al., 2011).

Bacterial decolorization was associated with the involvement of oxidoreductive enzymes, including azoreductase, NADH-DCIP reductase, tyrosinase, lignin peroxidase and laccase. The ability for dye detoxification using these enzymes was reported using different Bacillus strains including Bacillus velezensis strain $A B$ (Bafana et al., 2008), Bacillus subtilis (Pereira et al., 2009) and Bacillus sp. ADR (Telke et al., 2011). A new Pseudomonas putida strain shows a broader specificity of azoreductase for decolorization of some azo dyes (Mendes et al., 2011b).

The genus Lysobacter was first proposed by Christensen and Cook (1978) to be ubiquitous inhabitants of soil and water. Strains of Lysobacter were isolated from diverse sources in different parts from world, including; groundwater of a basement tile drain in Michigan, USA (Sullivan et al. 2003); upflow anaerobic blanket sludge reactors, Korea (Bae et al. 2005) and deep-sea sponge in Philippine Sea (Romanenko et al. 2008). Lysobacter spp. have been shown to be non-fastidious as to their nutrient requirements using Luria Bertani (LB) agar, nutrient broth (NB), Difco R2A medium (lkner et al., 2007) and 10\% tryptic soy agar (TSA) (Giesler and Yuen 1998). 
Novel hydrocarbon-degrading Lysobacter strains have been isolated from seawater and studied their ability to utilize recalcitrant compounds as its sole carbon and energy source. Maeda et al. (2009) reported the ability of marine Lysobacter to degrade carbasol to anthranilic acid when subjected to GC-MS analysis. Another Lysobacter sp. strain OC7 isolated from onshore sites was found to carry carbasol (CAR) - degrading genes (Maeda et al., 2010). Lysobacter was, recently, of great interest for taxonomical research as well as for bioremediation technologies and industrial applications (Zhang et al., 2011; Lou et al., 2012; Brito et al., 2012).

Thus, the main objective of this work was to study the ability of a new marine Lysobacter strain to degrade two azo dyes: methyl red and congo red under static condition. Enzymes involved in the degradation: DCIP reductase, tyrosinase, liginin peroxidase and azoreductase were assayed and metabolites formed after degradation were analysed using GC-MS and FTIR. Further, the toxicity potential of the two dyes was investigated during microbial degradation.

\section{MATERIALS AND METHODS}

\section{Microorganism and culture conditions}

Lysobacter sp was isolated from Abou Quir Gulf (Mediterranean Sea) near El Amya industrial pumping station considering enriched location contaminated with various dyes. Pure culture was maintained on nutrient agar slants. This organism was selected according to its ability to use commercial azo dyes as a sole carbon source. Composition of nutrient medium used for decolorization process was $(\mathrm{g} / \mathrm{L})$ : $\mathrm{NaCl} 5$, peptone 5 , beef extract 3 , dyes were used in a concentration of $100 \mathrm{mg} / \mathrm{L}$. The medium was adjusted at $\mathrm{pH} 7.5 ; 100 \mathrm{~mL}$ medium in $250 \mathrm{~mL}$ Erlenmeyer flasks was inoculated with $3 \mathrm{~mL}$ bacterial suspension $\left(10^{7} \mathrm{cell} / \mathrm{mL}\right)$ and incubated at $28 \pm 2$ ${ }^{\circ} \mathrm{C}$ until complete decolorization was achieved under static condition. Two controls were made; the first one was inoculated in dye free sterile medium, while the second control was made containing heat killed cells in concentration as that of culturing processes indicated the effect of medium components on the decolorization assay.

\section{Dyestuff and chemicals}

Some commercial dyes were obtained from El-Beada Dyers Company, Borg El-Arab, Alexandria, Egypt, including: black 5 , reactive turqouise blue, and cibacron violet, congo red (rosalmine), methyl red were tested for the decolorization by Lysobacter sp. The best wavelength $\left(\lambda_{\max }\right)$ for each dye $(555,520,542,506$ and 502 respectively) was measured after centrifuge of medium and the supernatant containing dyes was measured at the maximum wave length.

\section{S rRNA sequence analysis}

DNA was extracted from overnight pure culture of marine isolate using Qiagen DNeasy kit (QIAGEN-Inc., Germany) and Genomic DNA purification kit (Promegal). The purified DNA was amplified using a set of $16 \mathrm{~S}$ rRNA universal primer fD1 (5'-AGAGT TTGAT CCTGG CTCAG-3') and rP2 (5'-ACGGC TACCT TGTTA CGACTT-3') (Lee, et al., 2003) (f: forward; r: reverse; D: distal; P: proximal). The PCR product was purified and sequenced using BigDye $\AA$ Terminator v3.1 Cycle Sequencing kit (Applied Biosystems, Foster City, CA, USA) and model 3130xl Genetic Analyzer (Applied Biosystems, Foster City, CA, USA). Then, sequences were searched on BLAST tool (blastn) towards $\mathrm{nr} / \mathrm{nt}$ nucleotide sequence database in NCBI server (www.ncbi.nlm.nih.gov) and downloaded.

\section{Nucleotide sequence accession number}

The GenBank accession number for the sequences generated in this study is HM438544.1, the isolate was identified as Lysobacter sp. T312D9. This process was carried out at City for Scientific Research and Technology Applications, Genetic Engineering and Biotechnology Research Institute, the Environmental Biotechnology Department, New Borg El-Arab City, Alexandria, Egypt.

\section{Decolorization at different dye concentration}

Lysobacter sp. T312D9 was grown at $28 \pm 2{ }^{\circ} \mathrm{C}$ in $250 \mathrm{~mL}$ Erlenmeyer flasks containing $100 \mathrm{~mL}$ nutrient broth to study the effect of initial dye concentration on the decolorization in static condition, nutrient medium was added with $100,300,500,700$ and $1000 \mathrm{mg} / \mathrm{L}$ of the dyes. The aliquot $(3 \mathrm{~mL})$ of the culture media was withdrawn at different time intervals $(0,6,12,24,48,60,72 \mathrm{~h})$, centrifuged at $5000 \mathrm{rpm}$ for $10 \mathrm{~min}$. Decolorization was monitored by measuring the absorbance of cell free supernatant. Growth of microorganism was determined by the gravimetric method after drying at $80{ }^{\circ} \mathrm{C}$ until constant weight was reached. All decolorization experiments were performed in three sets.

The percentage decolorization was calculated as follows:

$\%$ Decolorization $=$ Initial absorbance - Observed absorbance Initial absorbance

\section{Enzyme assays}

All enzyme activities were assayed in cell free culture media at room temperature. Bacterial culture was centrifuged at $5000 \mathrm{rpm}$ for 30 minutes and the culture supernatant was further filtered through $0.45 \mathrm{~mm}$ pore size (Grid sterile cellulose membrane, Gelman laboratory). NADH-DCIP reductase assay was carried out using procedure of Salokhe and Govindwar (1999). Mixture composition $(5.0 \mathrm{~mL})$ was $25 \mu \mathrm{M}$ DCIP, $4.75 \mathrm{~mL}$ of potassium phosphate buffer (20 mM, pH 7.5) and $0.1 \mathrm{~mL}$ of enzyme solution. The reaction was initiated by addition of $50 \mu \mathrm{M} \mathrm{NADH}$. The decrease in color intensity of DCIP was observed at $595 \mathrm{~nm}$. Azoreductase assay was carried out using procedure of Chen et al. (2005). Composition of the assay mixture $(2.0 \mathrm{~mL})$ was $4.45 \mu \mathrm{M}$ of methyl red (MR), $100 \mu \mathrm{M} \mathrm{NADH}, 1.7 \mathrm{~mL}$ of potassium phosphate buffer $(20 \mathrm{mM}, \mathrm{pH}$ 7.5). The reaction mixture was pre- 
incubated for 4 min followed by the addition of NADH and monitored for the decrease in color absorbance $(430 \mathrm{~nm})$. The reaction was initiated by addition of $0.1 \mathrm{~mL}$ of the enzyme solution. Tyrosinase activity was determined in a reaction mixture of $2 \mathrm{~mL}$, containing $0.01 \%$ catechol in $0.1 \mathrm{M}$ phosphate buffer ( $\mathrm{pH} 7.4$ ) at $495 \mathrm{~nm}$ (Zhang and Flurkey, 1997). Lignin peroxidase (LiP) was determined by monitoring the formation of propanaldehyde at $300 \mathrm{~nm}$ in a reaction mixture of $2.5 \mathrm{~mL}$ containing $100 \mathrm{mM} \mathrm{n}$ propanol, $250 \mathrm{mM}$ tartaric acid, $10 \mathrm{mM} \quad \mathrm{H}_{2} \mathrm{O}_{2}$ (Shanmugam et al., 1999). One unit of enzyme activity was defined as amount of enzyme required to reduce $1 \mu \mathrm{M}$ of substrate $\mathrm{min}^{-1}$. All the enzyme assays were run in triplicates and average rates were calculated.

\section{Biodecolorization analysis}

Decolorization was monitored by UV-Vis spectroscopic analysis (Hitachi U-2800) whereas biodegradation was monitored by FTIR spectroscopy. Also, identification of metabolites was carried out by GC/MS. One hundred $\mathrm{mL}$ samples were taken after complete degradation, centrifuged at $10,000 \mathrm{rpm}$ and extraction of metabolites was carried from supernatant using equal volume of ethyl acetate. The extracts were dried over anhydrous $\mathrm{Na}_{2} \mathrm{SO}_{4}$ and evaporated to dryness in rotary evaporator. The biodegraded methyl red and congo red was characterized by Fourier Transform Infrared Spectroscopy (Perkin Elmer, Spectrum one) and compared with control dye. The FTIR analysis was done in the mid IR region of 400 $4000 \mathrm{~cm}^{-1}$ with 16 scan speed. The samples were mixed with spectroscopically pure $\mathrm{KBr}$ in the ratio of $5: 95$, pellets were fixed in sample holder, and the analyses were carried out.

Rotary vacuum evaporated sample was dissolved in methanol and GC/MS analysis of metabolites was carried out using a Hewlett Packard 989 B MS Engine, equipped with integrated gas chromatograph with a HP1 column (30 m long, $0.25 \mathrm{~mm}$ id, nonpolar). Helium was used as carrier gas at a flow rate of $1.1 \mathrm{~mL} / \mathrm{min}$. The injector temperature was maintained at $300^{\circ} \mathrm{C}$ with oven conditions as $100^{\circ} \mathrm{C}$ kept constant for 2 min then increased up to $250{ }^{\circ} \mathrm{C}$ with $10^{\circ} \mathrm{C} / \mathrm{min}$, raised up to $280^{\circ} \mathrm{C}$ with $30^{\circ} \mathrm{C} / \mathrm{min}$ rate. The compounds were identified on the basis of mass spectra and using the NIST library. Control with dye free sterile medium showed no peaks similar to those obtained in the presence of dye decolorizing medium.

\section{Toxicity study}

Toxicity bioassay was carried out using the brine shrimp Artemia salina. Two hundred mg ethyl acetate extract were dissolved in $2 \mathrm{~mL}$ DMSO. Different extract concentrations $(100,200,500,1000,1500,2000,4000$ and $6000 \mu \mathrm{g} / \mathrm{mL}$ ) were prepared, then $10 \mathrm{~mL}$ of sterile brackish water was added in $20 \mathrm{~mL}$ glass vials (three vials /concentration). Ten Artemia salina nauplii were transferred to each vial. Control vials free from extract with 10 nauplii were carried out. The number of the viable biomarker was counted after $24 \mathrm{~h}$ of application. The percentage of mortality and the half lethal concentration $\left(\mathrm{LC}_{50}\right)$ were determined using the probit analysis method (Mayer et al., 1982).

\section{Statistical analysis}

Data were analyzed by one-way analysis of Standard error using Origin lab 6.

\section{RESULTS AND DISCUSSION}

Marine bacteria are vital in recycling nutrients and could be useful for innovative applications, which are helpful to human beings. This study showed the isolated marine bacterial strain that able to decolorize two azo dyes, identified as Lysobacter sp T312D9 on the basis of 16S rRNA sequence where the phylogenetic relationship between this strain and other related microorganisms is shown in (Figure 1). The blast assay result indicated this strain belong to $\mathrm{Y}$-proteobacteria group.

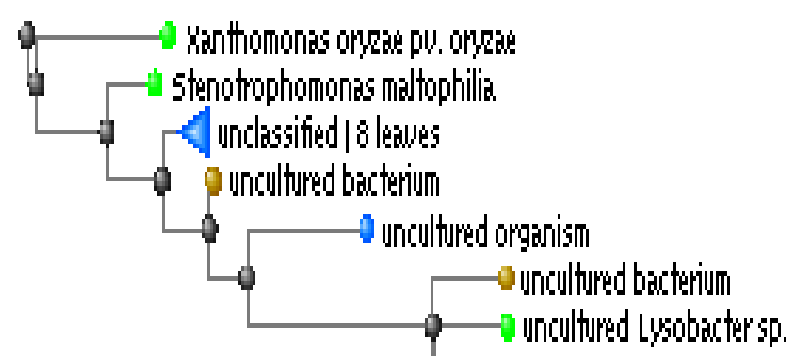

Figure 1: Phylogenetic analysis of 16 s rRNA sequence of Lysobacter sp. T312D9.Tree view for RID: N7EK26G901S, query ID: Ic||45967, database: nr.

\section{Decolorization of different azo-dyes}

As preliminary study, Lysobacter $\mathrm{sp}$. was able to decolorize various azo dyes at $100 \mathrm{mg} / \mathrm{L}$ in the nutrient broth. Complete removal of dye was observed for congo red and methyl red under static condition within $30 \mathrm{~h}$. Similar results using Comamonas sp VS-MH2 showed high metabolic activity towards mixture of reactive azo dye by degrading them completely at $100 \mathrm{mg} / \mathrm{L}$ within $30 \mathrm{~h}$ (Pathak et al., 2011). Ola et al. (2010) studied the ability of Bacillus cereus to decolorize two azo dyes cibacron black PSG and cibacron red P4B under aerobic conditions within 5 days. Another Bacillus sp. ADR also showed maximum decolorization of C.I. reactive orange 16 (100 mg/L) under static condition whereas less decolorization at shaking condition (Telke et al., 2009).

The other examined dye: reactive turquoise, cibacron violet and black5 showed a lower decolorization efficiency compared with congo and methyl red at 28,32 and $70 \%$, respectively, after $72 \mathrm{~h}$ of incubation.

\section{Effect of different dye concentrations}

Decolorization percent of congo red and methyl red by Lysobacter sp T312D9 was varied with initial dye 
concentrations: $100-1000 \mathrm{mg} / \mathrm{L} \quad$ (Figure 2). Dye degradation showed progress till $500 \mathrm{mg} / \mathrm{L}$ with efficiently decolorization activity $90-100 \%$ for methyl red and 95$100 \%$ for congo red within 30 h. Gradual decline of dyes removal above this concentration was observed till 1000 $\mathrm{mg} / \mathrm{L}$ which exhibited decolorization percent at $80 \%$ for congo and $88 \%$ methyl red within $72 \mathrm{~h}$. This gradually decline may occur due to the change in metabolic enzymes or accumulation of some by-products which have anti-decolorizing enzyme activity. Similar result was observed by Kalme et al. (2007) showing complete decolorization of 50 and $100 \mathrm{mg} / \mathrm{L}$ Direct Blue- 6 dye by Pseudomonas desmolyticum took 60 and $72 \mathrm{~h}$, respectively, while, more dye concentrations (150$200 \mathrm{mg} / \mathrm{L})$ resulted in $80-40 \%$ dye removal within $4-6$ days and no more exceed than $15 \%$ dye removal was observed at $250 \mathrm{mg} / \mathrm{L}$ dye concentration. Two Bacillus strains AK1and AK2 were capable of complete decolorizing Metanil Yellow azo dye $(200 \mathrm{mg} / \mathrm{L})$ within 27 and $12 \mathrm{~h}$, respectively, whereas, maximum dye concentration (1000 mg/L) was decolorized within 84 and 78 h, respectively (Anjaneya et al., 2011).
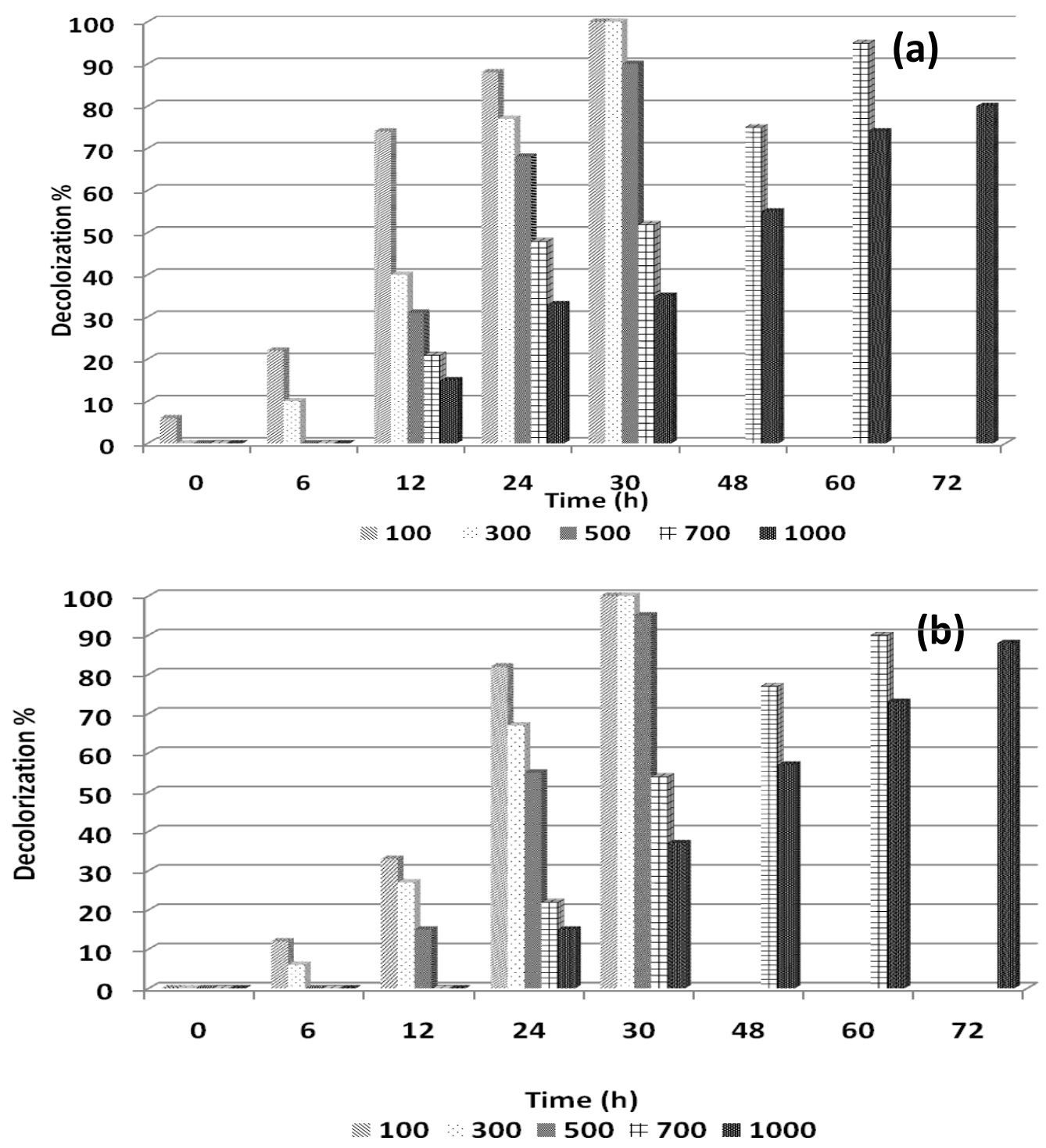

Figure 2: Decolorization percent of different methyl red (a) and congo red (b) concentrations at interval time using Lysobacter sp. T312D9 


\section{Enzymatic analysis}

Azo-enzyme, NADH- DCIP reductase and tyrosinase, showed gradual increase in activities during the time course of methyl red and congo red decolorization by Lysobacter sp. T312D9 (Table 1). High significant activities of NADH- DCIP reductase and tyrosinase at $24 \mathrm{~h}$ were recorded at 152 and $200 \%$ for methyl red and 239 and $200 \%$ for congo red as compared to 0 time. This is followed by lignin peroxidase induction activity, $150 \%$ for methyl red and $157 \%$ for congo red at $12 \mathrm{~h}$. Whereas, no significance was observed for azoreductase activity. These observations demonstrated that the significant induction of enzymes NADH-DCIP reductase and tyrosinase indicated their important role in the dye degradation. In contrast, Yang et al. (2011) studied the significant induction of NADH-DCIP reductase and azoreductase for the acid yellow 199 treatment by Shewanella oneidensis MR-1 at $192 \%$ and $248 \%$, respectively. Another report by Telke et al. (2010) showed no change in NADH-DCIP reductase activity, and decrease in azoreductase activity by $26 \%$ after $12 \mathrm{~h}$ of incubation for congo red decolorization by Pseudomonas sp. SU-EB.

Table 1 : Azo-Enzyme activities in $\mathrm{mg} / \mathrm{mg} / \mathrm{min}$ during the time course of Lysobacter sp. T312D9 decolorizing methyl red and congo red

\begin{tabular}{|c|c|c|c|c|c|c|}
\hline \multirow{2}{*}{ Dyes } & \multicolumn{6}{|c|}{ Enzyme activity (mg/mg/min) } \\
\hline & Time (h) & 0 & 6 & 12 & 24 & 30 \\
\hline \multirow{4}{*}{$\begin{array}{l}\text { Methyl } \\
\text { red }\end{array}$} & DCIP activity & $17.3 \pm 0.87$ & $19.7 \pm 0.99$ & $20.7 \pm 1.0$ & $26.3 \pm 1.3$ & $22.0 \pm 0.95$ \\
\hline & Azo reductase & $0.8 \pm 0.04$ & $0.8 \pm 0.04$ & $0.8 \pm 0.04$ & $0.8 \pm 0.04$ & $0.8 \pm 0.04$ \\
\hline & Tyrosinase & 0.2 & $0.2 \pm 0.3$ & $0.3 \pm 0.6$ & $0.4 \pm 1.5$ & $0.2 \pm 1.2$ \\
\hline & Lignin Peroxidase & $0.8 \pm 0.04$ & $1.0 \pm 0.05$ & $1.2 \pm 0.06$ & $0.9 \pm 0.04$ & $0.9 \pm 0.04$ \\
\hline \multirow{4}{*}{$\begin{array}{l}\text { Congo } \\
\text { red }\end{array}$} & DCIP activity & $25.2 \pm 1.3$ & $34.6 \pm 1.7$ & $44.2 \pm 2.2$ & $3 \pm 60.2$ & $1.9 \pm .39 .4$ \\
\hline & Azo reductase & $0.7 \pm 0.03$ & $0.7 \pm 0.04$ & $0.7 \pm 0.04$ & $0.7 \pm 0.04$ & $0.7 \pm 0.03$ \\
\hline & Tyrosinase & $0.3 \pm 0.01$ & $0.4 \pm 0.02$ & $0.4 \pm 0.02$ & $0.6 \pm 0.03$ & $0.3 \pm 0.01$ \\
\hline & Lignin Peroxidase & $0.7 \pm 0.03$ & $0.7 \pm 0.04$ & $1.1 \pm 0.06$ & $0.9 \pm 0.05$ & $0.9 \pm 0.05$ \\
\hline
\end{tabular}

Values are mean of three experiments \pm SEM (Standard error of mean), significantly different from control cells at P>0.05 using ORGIN $\mathrm{LAB}$ analysis

\section{Metabolites analysis}

For the biodegradation of azo dye, destruction of dye is a necessary because the removal of color is associated with the breaking of the chromophores i.e. conjugated unsaturated bond $(-\mathrm{N}=\mathrm{N}-)$ in molecules (Meric and Kaptan, 2004). Comparison of FTIR spectrum of methyl red and congo red "parent dyes" with their extracted metabolites clearly indicated the biodegradation by Lysobacter sp T312D9 (Figure 3a\&b). The FTIR spectrum of the two parent dyes showed peak at 1540 and 1578 $\mathrm{cm}^{-1}$ for $\mathrm{N}=\mathrm{N}$ stretching vibrations. Absence of these peaks after decolorization indicates cleavage of azo bond. This result was supported by Tekel et al., (2010), Kalme et al, (2007) and Kalyani et al. (2008) that reported the breakdown of azo bond due to the biodegradation of several azo dyes.

GC-MS analysis was carried out to investigate the metabolites formed after the biodegradation process (Table 2). The most suggested structures given with the NIST database were characterized as 1-alanine, N-(Oanisoyl)-,methyl ester and benzamine 2-ethoxy ophenetidine obtained from methyl red and congo red biodegradation, respectively. The two metabolites were different than N,N dimethyl aniline that found by Hsueh and Chen (2007), and 3-Hydroperoxy 8-nitrosonaphthol that found by Telke et al. (2010). According to the biodegradation route(s) in decolorization of methyl red and congo red by Lysobacter sp T312D9 that differ from the previous published works at least in the final steps (s) and this will be subjected for more studies.

\section{Metabolites toxicity}

The end products after dye biodegradation are of concern due to their environmental toxic effect. This experiment was carried out to detect the toxicity of different extracted metabolites concentrations. The results in Table 3 indicated low toxicity effect with maximum metabolites concentration at 2000 and $1500 \mu \mathrm{g} / \mathrm{mL}$ and the $\mathrm{LC}_{50}$ was found to be 3.3 and 3.2 after $24 \mathrm{~h}$ for methyl and congo red, respectively. This indicates that the decolorization process yielded less toxic metabolites, which may be safely discharged. Similar results were reported using phytotoxicity studies for azo dye biotreatment that revealed the less toxic nature of Reactive Red 2 (Kalyan 
Mal. J. Microbiol. Vol 9(1) 2013, pp. 93-102

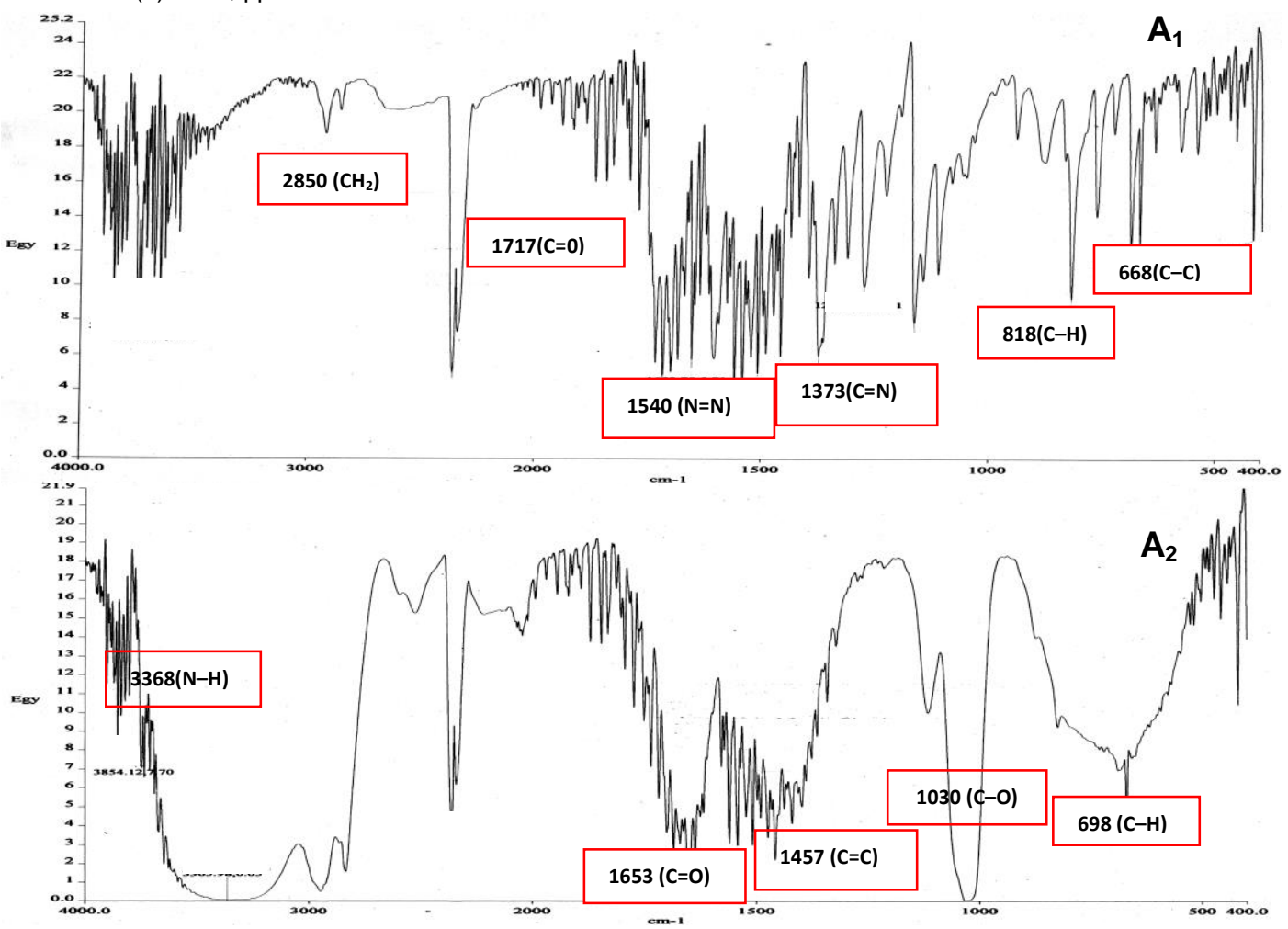

Figure 3a: FTIR spectrum of parent dye methyl red $\left(A_{1}\right)$ and its metabolite $\left(A_{2}\right)$ showing the absence of azo bond $(-N=N-)$ after decolorization process.

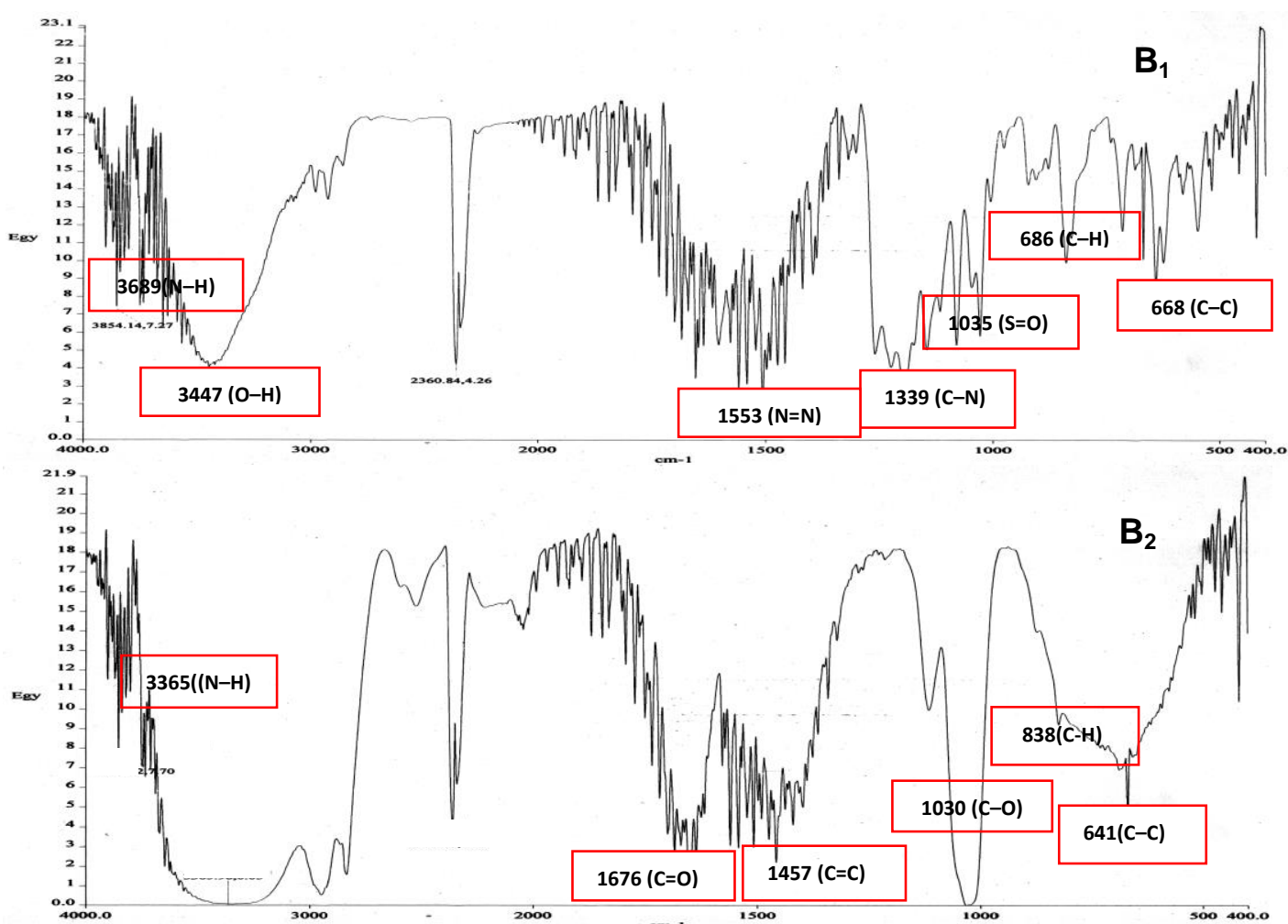

Figure 3b: FTIR spectrum of parent dye methyl red $\left(B_{1}\right)$ and its metabolite $\left(B_{2}\right)$ showing the absence of azo bond $(-N=N-)$ after decolorization process. 
Mal. J. Microbiol. Vol 9(1) 2013, pp. 93-102

Table 2: Gas chromatogram-Mass spectrum and suggested chemical structures of the two metabolites obtained after dye decolonization at different retention time

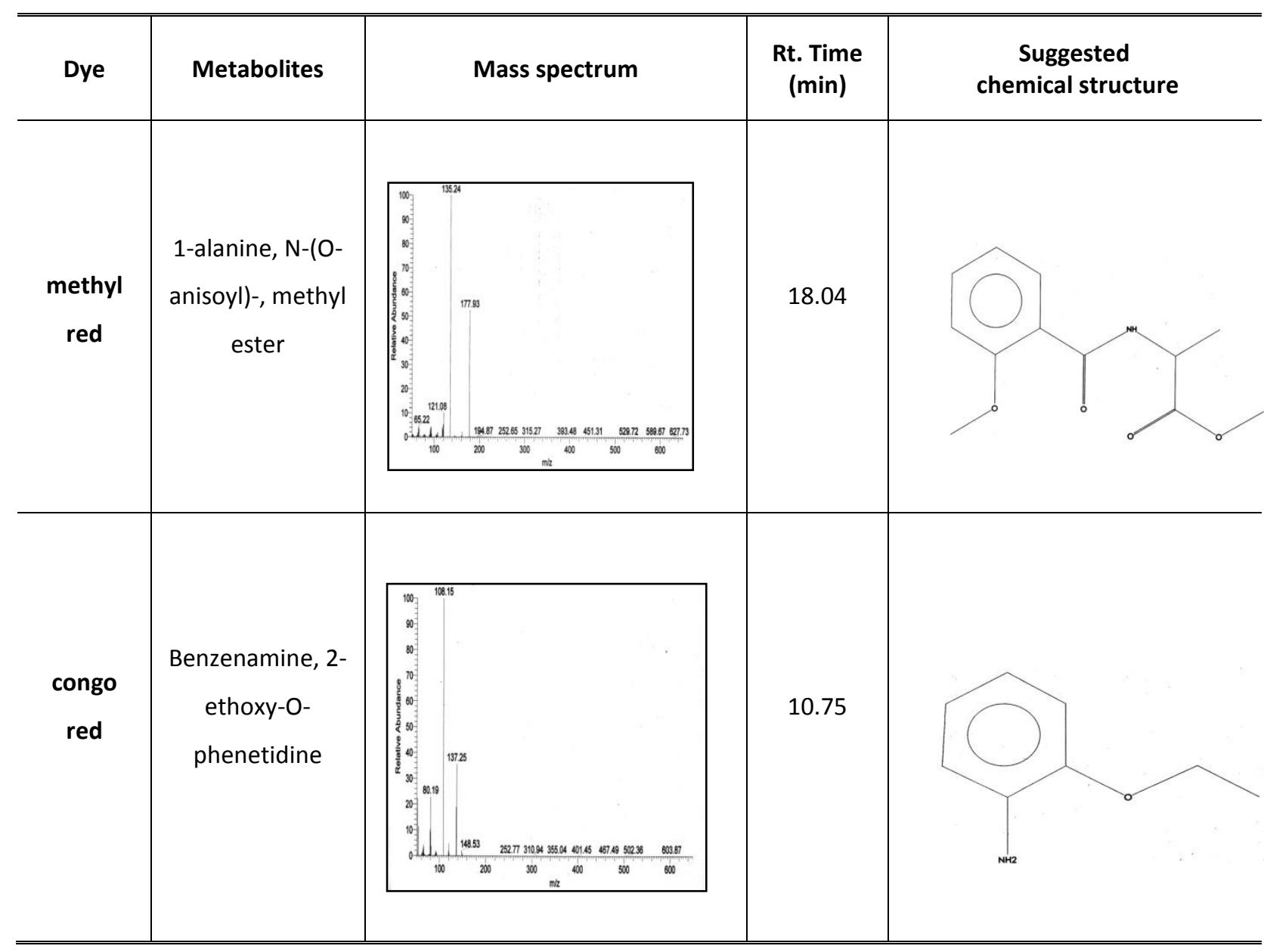

(a) metabolite from methyl red biodegradation

(b) metabolite from congo red biodegradation

Table 3: Toxicity of metabolites obtained after decolorization process using Artemia salina as biomarker

\begin{tabular}{lc|cc}
\hline Metabolite extracts & & \multicolumn{2}{|c}{ Mortality \% after 24h } \\
\cline { 3 - 3 } $\begin{array}{c}\text { concentration } \\
(\boldsymbol{\mu g} / \mathbf{m L})\end{array}$ & Log concentration & $\begin{array}{c}\text { Metabolite } \\
(\mathbf{a})\end{array}$ & $\begin{array}{c}\text { Metabolite } \\
(\mathbf{b})\end{array}$ \\
\hline 100 & & 0 & 15 \\
200 & 2.0 & 10 & 20 \\
500 & 2.3 & 10 & 35 \\
1000 & 2.6 & 20 & 47 \\
1500 & 3.0 & 45 & 50 \\
2000 & 3.2 & 50 & 65 \\
4000 & 3.3 & 60 & 80 \\
6000 & 3.6 & 80 & 95 \\
\hline \hline
\end{tabular}


et al., 2008), Reactive Yellow 84A (Dhanve et al., 2009), Congo Red (Telke et al., 2010) and seven commercial textile azo dyes (Kurade et al., 2011) metabolites. Also, Artemia salina biotoxicity tests were achieved for many degradable products from reactive textile dye showed the lowest toxicity level (Palácio et al., 2009; da Silva et al., 2011).

\section{REFERENCES}

Adedayo, O., Javadpour, S., Taylor, C., Anderson, W.A. and Moo-Young, M. (2004). Decolourization and detoxification of methyl red by aerobic bacteria from a wastewater treatment plant. World Journal of Microbiology and Biotechnology. 20(6): 545550.

Anjaneya, O., Souche, S.Y., Santoshkumar, M. and Karegoudar, T.B. (2011). Decolorization of sulfonated azo dye Metanil Yellow by newly isolated bacterial strains: Bacillus sp. strain AK1 and Lysinibacillus sp. strain AK2. Journal of Hazard Mater. 190(1-3): 351-358.

Asad, S., Amoozegar, M.A., Pourbabaee, A.A., Sarbolouki, M.N. and Dastgheib, S.M.M. (2007). Decolorization of textile azo dyes by newly isolated halophilic and halotolerant bacteria. Bioresource Technology. 98: 2082-2088.

Bae, H.-S., Im, W.-T. and Lee, S.-T. (2005). Lysobacter concretionis sp. nov., isolated from anaerobic granules in an upflow anaerobic sludge blanket reactor. International Journal of Systematic and Evolutionary Microbiology. 55: 1155-1161.

Bafana, A., Chakrabarti, T. and Devi, S.S. (2008). Azoreductase and dye detoxification activities of Bacillus velezensis strain AB. Applied Microbiology and Biotechnology. 77(5): 1139-1144.

Brito, E.M., Piñón-Castillo, H.A., Guyoneaud, R., Caretta, C.A., Gutiérrez-Corona, J.F., Duran, R., Reyna-López, G.E., Nevárez-Moorillón, G.V., Fahy, A. and Goñi-Urriza, M. (2012). Bacterial biodiversity from anthropogenic extreme environments: a hyper-alkaline and hyper-saline industrial residue contaminated by chromium and iron. Applied Microbiology and Biotechnology. [Epub ahead of print].

Chen, H., Hopper, S.L. and Cerniglia, C.E. (2005). Biochemical and molecular characterization of an azoreductase from Staphylococcus aereus A tetrameric NADPH-dependent flavoprotein. Microbiology. 151: 1433-1441.

Christensen, P. and Cook, F.D.(1978). Lysobacter, a new genus of non-fruiting, gliding bacteria with a high base ratio. International Journal of Systematic Bacteriology. 28:367-393.

da Silva, M.R., de Sá, L.R., Russo, C., Scio, E. and Ferreira-Leitão, V.S. (2011). The use of HRP in decolorization of reactive dyes and toxicological evaluation of their products. Enzyme Resources. PMID 21318147.

Dhanve, R.S., Kalyani, D.C., Phugare, S.S. and Jadhav, J.P. (2009). Coordinate action of exiguobacterial oxidoreductive enzymes in biodegradation of reactive yellow $84 \mathrm{~A}$ dye. Biodegradation. 20(2): 245-255.

Ergene, A., Adab, K., Tana, S. and Katırcıoğlu, H. (2009). Removal of remazol brilliant blue $R$ dye from aqueous solutions by adsorption onto immobilized Scenedesmus quadricauda: Equilibrium and kinetic modeling studies. Desalination. 249(3): 1308-1314.

Feng, J., Cerniglia, C.E. and Chen, H. (2012). Toxicological significance of azo dye metabolism by human intestinal microbiota. Front Bioscience. (Elite Ed). 1(4): 568-586.

Figueroa, S., Va'zqueza, L. and Alvarez-Gallegos, A. (2009). Decolorizing textile wastewater with Fenton's reagent electrogenerated with a solar photovoltaic cell. Water Research. 43: 283-294.

Giesler, L. and Yuen, G. (1998). Evaluation of Stenotrophomonas maltophilia strain C3 for biocontrol of brown patch disease. Crop Protection. 17: 509-513

Hsueh, C.C. and Chen, B.Y. (2007). Comparative study on reaction selectivity of azo dye decolorization by Pseudomonas luteola. Journal of Hazard Mater. 141: 842-849.

Ikner, L., Toomey, R., Nolan, G., Neilson, J., Pryor, B. and Maier, R. (2007). Culturable Microbial Diversity and the Impact of Tourism in Kartchner Caverns, Arizona. Microbiol Ecology. 53: 30-42.

Khehra, M.S., Saini, H.S., Sharma, D.K., Chadha, B.S. and Chimni, S.S. (2006). Biodegradation of azo dye C.I. Acid Red 88 by an anoxic-aerobic sequential bioreactor. Dyes and Pigments. 70: 1-7.

Kalme, S.D., Parshetti, G.K., Jadhav, S.U. and Govindwar, S.P. (2007). Biodegradation of benzidine based dye direct blue- 6 by Pseudomonas desmolyticum NCIM 2112. Bioresource Technology. 98:1405-1410.

Kalyani, D.C., Patil, P.S., Jadhav, J.P. and Govindwar, S.P. (2008). Biodegradation of reactive textile dye Red BLI by an isolated bacterium Pseudomonas sp. SUK1. Bioresource Technology. 99: 46354841.

Kalyani, D.C., Telke, A.A., Dhanve, R.S. and Jadhav, J.P. (2009). Ecofriendly biodegradation and detoxification of Reactive Red 2 textile dye by newly isolated Pseudomonas sp. SUK1. Journal of Hazard Mater. 163: 735-742.

Kumar, K., Saravanadevi, S., Krishnamurthi, K., Gampawar, S., Mishra, N., Pandya, G.H. and Chakrabarti, T. (2006). Decolorization, biodegradation and detoxification of benzidine based azo dye. Bioresource Technology. 97:407413.

Kurade, M.B., Waghmode, T.R. and Govindwar, S.P. (2011). Preferential biodegradation of structurally dissimilar dyes from a mixture by Brevibacillus laterosporus. Journal of Hazard Mater. 192(3): 746-755.

Lee, J.Y., Moon, S.S., and Hwang, B.K. (2003). Isolation and antifungal and antioomycete activities of 
Mal. J. Microbiol. Vol 9(1) 2013, pp. 93-102

aerugine produced by Pseudomonas fluorescens Strain MM-B16. Applied Environmental Microbiology. 69: 2023-2031.

Lou, L., Chen, H., Cerny, R.L., Li, Y., Shen, Y. and Du, L. (2012). Unusual activities of the thioesterase domain for the biosynthesis of the polycyclic tetramate macrolactam HSAF in Lysobacter enzymogenes C3. Biochemistry. 51(1): 4-6.

Maeda, R., Nagashima, H., Widada, J., Iwata, K. and Omori, T. (2009). Novel marine carbazoledegrading bacteria. FEMS Microbiology Letter. 292(2): 203-209.

Maeda, R., Ito, Y., Iwata, K. and Omori, T. (2010). Comparison of marine and terrestrial carbazole degrading bacteria. Current research, technology and Education Topics in Applied Microbiology and Microbial Biotechnology. A. Mendez - Vilas (Ed.): 1311- 1321.

Mane, U.V., Gurav, P.N., Deshmukh, A.M. and Govindwar, S.P. (2008). Degradation of textile dye reactive navy blue $R X$ (Reactive blue-59) by an isolated Actinomycete Streptomyces krainskii SUK5. Malaysian Journal of Microbiology. 4:1-5.

Mansour, H.B., Ghedira, K., Barillier, D., Ghedira, L.C. and Mosrati, R. (2011). Degradation and detoxification of acid orange 52 by Pseudomonas putida mt-2: a laboratory study. Environ. Sci. Pollut. Res. Int. 18( 9):1527-1535.

Mayer, B.N., Ferrigni, N.R., Putnam, J.E., Jacobsen, L.B., Nichols, D.E. and Melaughhlin, J.L. (1982). Brine Shrimp: Aconvenient General Bioassay for Active plant constituents. Journal of Planta Medical. 45: 31-34.

Mendes, S., Pereira, L., Batista, C. and Martins, L.O. (2011a). Molecular determinants of azo reduction activity in the strain Pseudomonas putida MET94. Applied Microbiology and Biotechnology. 92(2): 393-405.

Mendes, S., Farinha, A., Ramos, C.G., Leitão, J.H, Viegas, C.A. and Martins, L.O. (2011b). Synergistic action of azoreductase and laccase leads to maximal decolourization and detoxification of model dye-containing wastewaters. Bioresource Technology. 102(21):9852-9859.

Meric, S., Kaptan, D., Imez, T. O. (2004). Color and COD removal from wastewater containing Reactive Black 5 using Fenton's oxidation process Chemosphere. 54 (3): 435-441.

Ola, I.O., Akintokun, A.K., Akpan, I., Omomowo, I.O., Areo, V.O. (2010). Aerobic decolourization of two reactive azo dyes under varying carbon and nitrogen source by Bacillus cereus. African Journal of Biotechnology. 9(5): 672-677.

Palácio, S.M., Espinoza-Quiñones, F.R., Módenes, A.N., Oliveira, C.C., Borba, F.H. and Silva, F.G.Jr. (2009). Toxicity assessment from electrocoagulation treated-textile dye wastewaters by bioassays. Journal of Hazard Mater. 172(1):330337.

Pathak, H., Patel, S., Rathod, M. and Chauhan, K. (2011). In vitro studies on degradation of synthetic dye mixture by Comamonas sp. VS-MH2 and evaluation of its efficacy using simulated microcosm. Bioresource Technology. 102(22): 10391-10400.

Pereira, L., Coelho, A.V., Viegas, C.A., Santos, M.M., Robalo, M.P. and Martins, L.O. (2009). Enzymatic biotransformation of the azo dye Sudan Orange $G$ with bacterial CotA-laccase. Journal of Biotechnology. 139(1): 68-77.

Priya, B., Uma, L., Ahamed, A.K., Subramanian, G. and Prabaharan, D. (2011). Ability to use the diazo dye, C.I. Acid Black 1 as a nitrogen source by the marine cyanobacterium Oscillatoria curviceps BDU92191. Bioresource Technology. 102(14): 7218-7223.

Romanenko, L.A., Uchino, M., Tanaka, N., Frolova, G. M. and Mikhailov, V.V. (2008). Lysobacter spongiicola sp. nov., isolated from a deep-sea sponge. International Journal of Systematic and Evolutionary Microbiology. 58: 370-374.

Salokhe, M.D. and Govindwar, S.P. (1999). Effect of carbon source on the biotransformation enzymes in Serratia marcescens. World Journal of Microbiology and Biotechnology. 15: 229-232.

Saritha, V., Maruthi, Y. and Mukkanti, K. (2010). Biological decolourization of higher concentrations of synthetic lignin by native fungi. Journal of Environmental Resource Management. 1(1): 1-4.

Shanmugam, V., Kumari, M. and Yadav, K.D. (1999). nproponol as substrate for assaying the lignin peroxidase activity of Phanerochaete chrysoporium. Indian Journal of Biochemistry and Biophysics. 36:39-43.

Sullivan, R.F., Holtman, M.A., Zylstra, G.J., White, J.F., Kobayashi, D.Y. (2003). Taxonomic positioning of two biological control agents for plant diseases as Lysobacter enzymogenes based on phylogenetic analysis of $16 \mathrm{~S}$ rDNA, fatty acid composition and phenotypic characteristics. Journal of Applied Microbiology. 94:1079-1086.

Telke, A.A., Kalyani, D.C., Jadhav, J.P. and Govindwar, S.P. (2008). Kinetics and mechanism of reactive red 141 degradation by a bacterial isolate Rhizobium radiobacter MTCC 8161. Acta Chimica Slovenica. 55: 320-329.

Telke, A.A., Kalyania, D.C., Dawkara, V.V. and Govindwar, S.P. (2009). Influence of organic and inorganic compounds on oxidoreductive decolorization of sulfonated azo dye C.I. Reactive Orange 16. Journal of Hazard Mater. 172(1): 298309.

Telke, A.A., Joshi, S.M., Jadhav, S.U., Tamboli, D.P. and Govindwar, S.P. (2010). Decolorization and detoxification of congo red and textile industry effluent by an isolated bacterium Pseudomonas sp. SU-EBT. Biodegradation. 21: 283-296.

Telke, A.A., Ghodake, G.S., Kalyani, D.C., Dhanve, R.S. and Govindwar, S.P. (2011). Biochemical characteristics of a textile dye degrading extracellular laccase from a Bacillus sp. ADR. Bioresource Technology. 102(2):1752-1756. 
Mal. J. Microbiol. Vol 9(1) 2013, pp. 93-102

Yang, Y.Y., Du, L.N., Wang, G., Jia, X.M. and Zhao, Y.H. (2011). The decolorisation capacity and mechanism of Shewanella oneidensis MR-1 for methyl orange and acid yellow 199 under microaerophilic conditions. Water Science Technology. 63(5): 956-963.

Zhang, X. and Flurkey, W. (1997). Phenoloxidases in Portabel mushrooms. Journal of Food Science. 62: $97-100$.

Zhang, W., Li, Y., Qian, G., Wang, Y., Chen, H., Li, Y.Z., Liu, F., Shen, Y. and Du, L. (2011). Identification and characterization of the anti-methicillin-resistant Staphylococcus aureus WAP-8294A2 biosynthetic gene cluster from Lysobacter enzymogenes $\mathrm{OH} 11$. Antimicrobial Agents and Chemotherapy. 55(12): 5581-5589. 